\title{
Diversity and cytological studies of the Genus Amomum Roxb. former Elettariopsis Baker (Zingiberaceae) in Thailand
}

\author{
PIYAPORN SAENSOUK ${ }^{1}$, SURAPON SAENSOUK ${ }^{2, v}$ \\ ${ }^{1}$ Plant and Invertebrate Taxonomy and Its Applications Unit Group, Department of Biology, Faculty of Science, Mahasarakham University. \\ Kantharawichai, Maha Sarakham, 44150, Thailand \\ ${ }^{2}$ Plant and Invertebrate Taxonomy and Its Applications Unit Group, Biodiversity Program, Walai Rukhavej Botanical Research Institute, Mahasarakham \\ University. Kantarawichai, Maha Sarakham, 44150, Thailand `email: surapon.s@msu.ac.th
}

Manuscript received: 4 April 2021. Revision accepted: 17 May 2021

\begin{abstract}
Saensouk P, Saensouk S. 2021. Diversity and cytological studies on the genus Amomum Roxb. former Elettariopsis Baker (Zingiberaceae) in Thailand. Biodiversitas 22: 3209-3218. A comprehensive diversity and cytological studies of the genus Amomum Roxb. in Thailand have not been reported. This work aims to study the diversity and cytological including chromosome numbers and karyotypes of the genus Amomum Roxb. former Elettariopsis Bakerin Thailand. Ten species of Amomum were recognized from Thailand. Nomenclatures, vernacular names, distribution, ecology, and traditional utilization are provided. Only Amomum wandokthong is widely cultivated in all parts in Thailand. Four living species, i.e. Amomum curtisii, A. monophyllum, A. trilobum, and A. wandokthong have been collected from field trips. Therefore, the somatic chromosome numbers from four species of this genus were studied from root tips. The somatic chromosome numbers of each species in this study were counted from 20 cells. The karyotype formulas were derived from measurements of the metaphase chromosomes in photomicrographs. The chromosome numbers of four species were found to be $2 \mathrm{n}=48$. Karyotypes of four species were reported to be Amomum curtisii $(32 \mathrm{~m}+8 \mathrm{sm}+8 \mathrm{st})$, A. monophyllum (26m $+12 \mathrm{sm}+10 \mathrm{st})$, A. trilobum $(18 \mathrm{~m}+24 \mathrm{sm}+6 \mathrm{st})$, and A. wandokthong $(28 \mathrm{~m}+16 \mathrm{sm}+4 \mathrm{st}$ with five visible satellites chromosomes $)$. The chromosome numbers of A. monophyllum and A. wandokthong were reported for the first time. The karyotypes of four species were studied for the first time.
\end{abstract}

Keywords: Amomum, cytogenetic, Elettariopsis, plant diversity, Thailand

\section{INTRODUCTION}

Zingiberaceae or the ginger family is aromatic perennial herbs with creeping horizontal or tuberous rhizomes. It consists of about 57 genera and a total of about 1,600 known species in the world (http://www.ipni.org and http://apps.kew.org/wcsp/) and distributed throughout tropical Africa, Asia, and the Americas, with Southeast Asia as the center of diversity for this family (Kress et al. 2007; Leong-Škorničková et al. 2019). Zingiberaceae in Thailand is found as more than 26 genera and over 300 species, and the numbers will most certainly rise (Boer et al. 2018).

The genus Amomum is established by Roxburgh (1820). It is flowering plants in the tribe Alpinieae, subfamily Alpinioideae, family Zingiberaceae with consists of approximately 69 species, of which almost 30 were previously in ElettariopsisBaker.Amomumis small to largesized herbs, clump-forming to loosely clump-forming, or creeping. This genus can be distinguished from other closely related genera by the following combination of characters: labellum white with a yellow patch in the center and usually with red markings, or yellow with or without red markings; lateral staminodes small or absent; anthers with a well-developed fan-shaped and more or less obscurely trilobed crest or with an extended, longer than wide and often bluntly rectangular crest (in most species previously classified as Elettariopsis) (Ye et al. 2021). It includes several species of cardamom that are remarkable for their pungency and aromatic. A few years ago, former the small genus Elettariopsis is established by Baker (1892). It has now been subsumed into the genus Amomum based on molecular data in a multi-marker phylogenetic framework using matK and nrITS including multiple accessions of the species (Boer et al. 2018). Therefore, the genus Elettariopsis is a synonym of the genus Amomum which is accepted genus and species (Kress et al. 2007; Boer et al. 2018).

The center of diversity of the genus Amomum is distributed mainly in Southeast Asia. In Thailand, few botanists, i.e. Picheansoonthon and Yupparach (2007), Saensouk and Saensouk (2014), and Saensouk et al. (2016), studied Amomum including previously in genus Elettariopsis. Most of them are traditionally used as local food (including ingredients), medicinal, ornamentals, and in rituals Saensouk et al. (2016).

The chromosome number of Amomum former Elettariopsis were studied by few workers i.e. Kam (1982) (four species) and Beltran and Kam (1984) (three species) reported to be $n=24$ while Eksomtramage et al. (2001) and Saenprom et al. (2018) reported being $2 n=48$. The karyotype of this genus was studied only in E. biphyllaby Saenprom et al. (2018). This work aims to study the diversity and some cytological including chromosome numbers and karyotypes of the genus Amomum in Thailand. 


\section{MATERIALS AND METHODS}

\section{Plant materials}

Some plant materials were collected from field trips in Thailand between 2018 and 2020 (Table 1). Some voucher specimens were deposited at the Mahasarakham University Herbarium, Thailand. Four living species, i.e. Amomum curtisii, A. monophyllum, A. trilobum and A. wandokthong were grown at Mahasarakham Plant Nursery, the Center of Excellence for Silk Innovation, Division of Research Facilitation and Dissemination, Mahasakham University for karyological studies.

\section{Plant diversity study}

Plant diversity, vernacular names, distribution data, and ecological data were taken from the field, herbarium specimens, and available literature. The morphological characters, such as leaf, leaf-sheath, inflorescence, bract, bracteole, flower, calyx, corolla lobe, labellum, lateral staminode, stamen, stigma, ovary were studied under stereo microscopy. The specimens in this study were compared with herbarium specimens which kept aboard herbaria (AAU, BK, BKF, E, K, P, KKU, and QBG), available taxonomic literature, i.e. Picheansoonthon and Yupparach (2007), Saensouk and Saensouk (2014) and Saensouk et al. (2016) or digital images available online and all the published studies of species of Amomum (Table 1). The distribution data and ecological data were taken from the field, herbarium specimens, and available taxonomic literature.

\section{Traditional utilization study}

Traditional utilization data was taken from interviews with local people near the site locality of each species, herbarium specimens, and available taxonomic literature.

\section{Karyology study}

Chromosome numbers were studied from root tips of four species. Root tips were collected in the morning after sunrise. The root tips of all specimens were pretreated with paradichlorobenzene (PDB) at $4^{\circ} \mathrm{C}$ for $6 \mathrm{~h}$, fixed in ethanol-acetic acid $(3: 1, \mathrm{v}: \mathrm{v})$ at room temperature for 30 min and stored at $4^{\circ} \mathrm{C}$ or used immediately. Samples were washed in distilled water, hydrolyzed in $1 \mathrm{M} \mathrm{HCl}$ for $5 \mathrm{~min}$ at $60^{\circ} \mathrm{C}$ and washed again in distilled water, then they were stained and squashed in $2 \%$ aceto-orcein, and then they were observed under a microscope (Zeiss Axiostar Plus) (Saenprom et al. 2018). The somatic chromosome numbers of each species in this study are counted from 20 cells. The karyotype formulas were derived from measurements of the metaphase chromosomes in photomicrographs. The nomenclature used for the description of the chromosome morphology is that proposed by Levan et al. (1964).

\section{RESULTS AND DISCUSSION}

\section{Diversity of the genus Amomum former Elettariopsis from Thailand}

Amomum Roxb. is accepted genus, and its native range is Tropical and Subtropical Asia to N. Queensland(Ye et al. 2021). Recently, ten species of the genus Amomum former Elettariopsis in Thailand (Table 1), namely Amomum biphyllum (Saensouk \& P. Saensouk) Skornick. \& Hlavatá, A. chayanianum (Yupparach) Skornick. \& Hlavatá, A.curtisii (Baker) Skornick. \& Hlavatá, A. elan (C.K. Lim) Skornick. \& Hlavatá, A. exertum (Scort.)Skornick. \& Hlavatá, A. monophyllum Gagnep., A. slahmong (C.K. Lim) Skornick. \& Hlavatá, A. smithiae (Y.K. Kam) Skornick. \& Hlavatá, A. trilobum Gagnep. and A. wandokthong (Picheans. \& Yupparach) Skornick. \& Hlavatá were reported.

Table 1 The genus Amomum former Elettariopsis in Thailand

\begin{tabular}{|c|c|c|}
\hline Species & Site localities & References \\
\hline $\begin{array}{l}\text { Amomum biphyllum (Saensouk \& } \\
\text { P.Saensouk) Skornick. \& Hlavatá }\end{array}$ & $\begin{array}{l}\text { North-Eastern: Bueng Kan province } \\
\text { (PhuWua Wildlife Sanctuary). }\end{array}$ & Saensouk and Saensouk (2014) \\
\hline $\begin{array}{l}\text { A. chayanianum (Yupparach) Skornick. } \\
\text { \&Hlavatá }\end{array}$ & $\begin{array}{l}\text { Khao Sapan Hin Range of AmphoreKlung, } \\
\text { Chantaburi province }\end{array}$ & Picheansoonthon and Yupparach (2007) \\
\hline A. curtisii (Baker) Skornick. \& Hlavatá & $\begin{array}{l}\text { Peninsular Thailand: Nakhon Si Thammarat } \\
\text { (KhaoLuang), Phattalung province }\end{array}$ & Picheansoonthon and Yupparach (2007) \\
\hline A. elan (C.K.Lim) Skornick. \& Hlavatá & Peninsular Thailand: Yala (Hala Forest) & Picheansoonthon and Yupparach (2007) \\
\hline $\begin{array}{l}\text { Amomum exertum (Scort.) Skornick. \& } \\
\text { Hlavatá }\end{array}$ & $\begin{array}{l}\text { Peninsular Thailand: Yala (PhuKhao Thong, } \\
\text { Bala Forest) }\end{array}$ & Picheansoonthon and Yupparach (2007) \\
\hline A. monophyllum Gagnep. & $\begin{array}{l}\text { North-eastern Thailand: BuengKan, Nakhon } \\
\text { Phanom }\end{array}$ & Picheansoonthon and Yupparach (2007) \\
\hline A. slahmong (C.K.Lim) Skornick. \&Hlavatá & $\begin{array}{l}\text { Peninsular Thailand: Yala (Phu Khao Thong, } \\
\text { Bala Forest) }\end{array}$ & Picheansoonthon and Yupparach (2007) \\
\hline A. smithiae (Y.K.Kam) Skornick. \&Hlavatá & $\begin{array}{l}\text { Peninsular Thailand:SongKla (Than Pliu } \\
\text { Waterfall), Satun (Thaleban National Park) }\end{array}$ & Picheansoonthon and Yupparach (2007) \\
\hline A. trilobum Gagnep. & $\begin{array}{l}\text { North-eastern Thailand: KhonKaen, Sakon } \\
\text { Nakhon (Phu Phan) }\end{array}$ & $\begin{array}{l}\text { Picheansoonthon and Yupparach (2007), } \\
\text { Saensouk et al. (2016) }\end{array}$ \\
\hline $\begin{array}{l}\text { A. wandokthong (Picheans. \&Yupparach) } \\
\text { Skornick. \& Hlavatá }\end{array}$ & All parts in Thaiand & Picheansoonthon and Yupparach (2007) \\
\hline
\end{tabular}




\section{Morphological characters of Amomum former Elettariopsis from Thailand}

Morphological characters were described base on living specimens, herbarium specimens and available literature as follows: perennial herbs, up to $150 \mathrm{~cm}$ tall. Rhizomes creeping, slender, bearing pseudostems at intervals. Leaves 1-8; ligule entire or 2-lobed; petiole erect, long; leaf blade ovate, lanceolate, elliptic, or oblong. Inflorescences arising from the base of pseudostems, with flowers spaced along rachis or sometimes in an erect, dense head; rachis prostrate or erect, simple or branched; bracts 1- or 2flowered; bracteoles open, not tubular. Flowers white or pinkish; calyx white or pinkish, tubular, apex 2- or 3toothed; corolla tube longer than calyx, slender; lobes 3 , ovate-oblong or elliptic; lateral staminodes absent or very short; filament short and broad; connective appendage \pm quadrate, lateral lobes not spreading; ovary 3-loculed; ovules numerous per locule. Stigma obconical, ciliate; styloides 2, slender. Fruits capsule, globose, glabrous. Seeds numerous, elliptic-globose, 4-5 mm, covered entirely with gelatinous aril.

\section{Key to species}

The key to species of Amomum former Elettariopsis from Thailand is constructed base on the morphology from living specimens, herbarium specimens, and available literature as follows:

1.a. Scape with flowers in a dense head $\ldots \ldots \ldots \ldots \ldots \ldots \ldots \ldots . \ldots . \ldots . \ldots . \ldots 2$ 1.b. Scape with flowers spaced along a decurrent rachis .......... 7

2.a. Leaves prominently veined A. slahmong

2.b. Leaves not prominently veined .... 3

3.a. Anther crest with a small tooth-like lobe at the base on each side ................................................... 4 3.b. Anther crest without a small tooth-like lobe at the base ....... 5

4.a. Ligule glabrous A. trilobum 4.b. Ligule puberulo A. wandokthong

5.a. Leaf base attenuate A. elan

5.b. Leaf base obliquely acute 6

6.a. Leaf apex acuminate to shortly caudate, leaf $2-4$

A. chayaniana

6.b. Leaf apex mucronate, leaf one A. monophyllum

7.a.Leaf shape lanceolate; leaves 8

7.b.Leaf shape elliptic; leaves 2-3-5 A. smithiae

8.a. Leaves 2

8.b. Leaves 3-5

A. biphyllum

9.a. Leaf blade $15-20 \times 40-68 \mathrm{~cm}$; leaves 3

A. exsertrum

9.b. Leaf blade $5-12 \times 8-25 \mathrm{~cm}$; leaves 5

Amomum biphyllum (Saensouk \& P. Saensouk) Skornick. \& Hlavatá

Synonym: Elettariopsis biphylla Saensouk \& P. Saensouk

Vernacular names. Khing-Nok-Kho (Thailand)

Distribution. It is endemic to Thailand, only known from BuengKan Province Bung Khla District, (PhuWua Wildlife Sanctuary) (Figure 1).

Ecology. This species grows in the shade of mixed deciduous to dry evergreen forest at an elevation of c. 140 $\mathrm{m}$ asl.

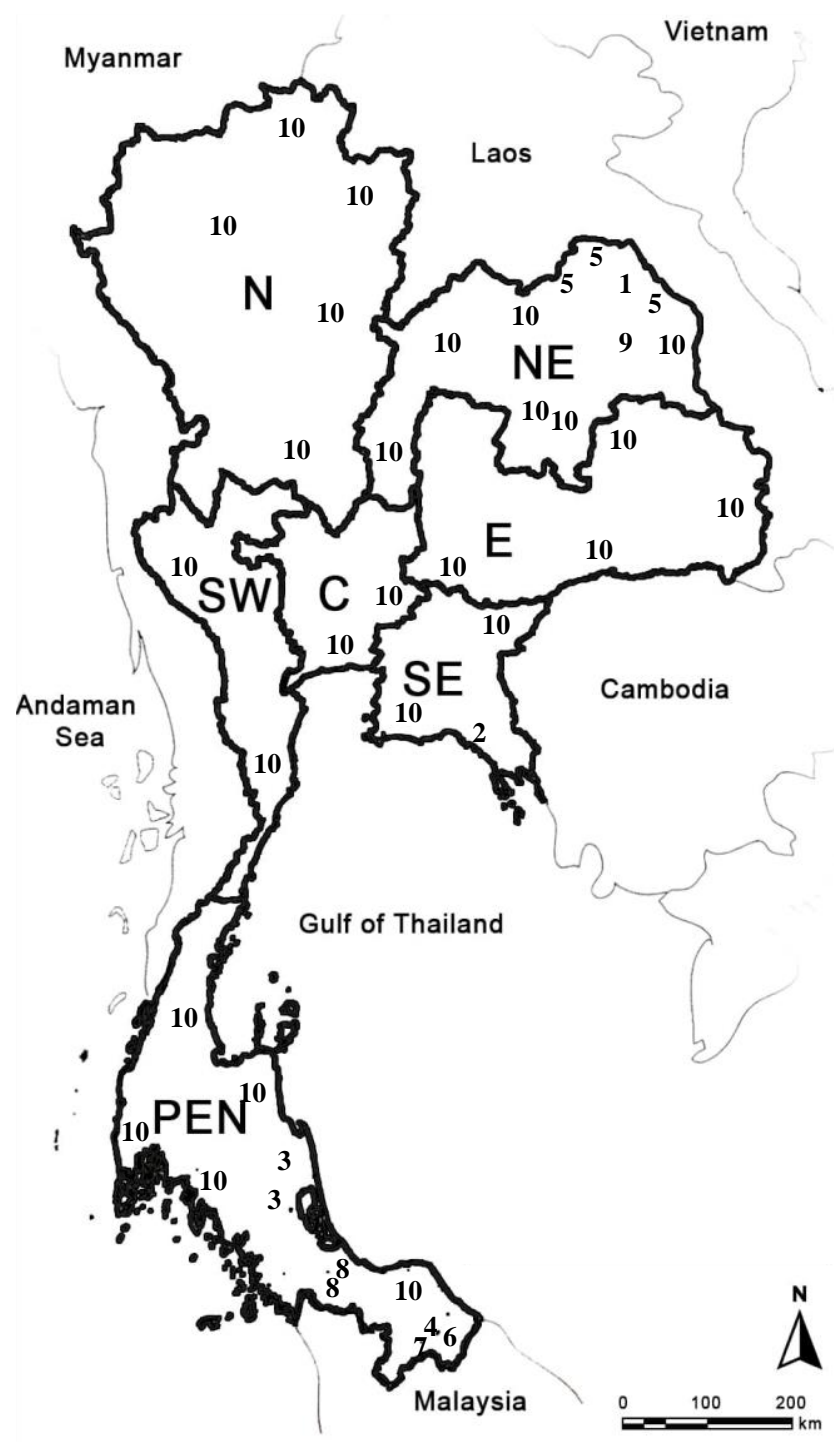

Figure 1. Map of Thailand with neighbor countries showing the distribution of ten species of Amomum former Elettariopsis from Thailand. 1. Amomum biphyllum, 2. A. chayanianum, 3. A. curtisii, 4. A. elan, 5. A. monophyllum, 6. A. exertum, 7. A. slahmong, 8. A. smithiae, 9. A. trilobum, and 10. A. wandokthong (Phytogeographical areas of Thailand as used in the Flora of Thailand project. Provincial borders are indicated. N: Northern, NE: North-eastern, E: Eastern, SW: South-western, C: Central, SE: South-eastern, PEN: Peninsular)

Note. The species has two distinctive leaves and dark red veins in parts of the labellum. The morphological characters of $A$. biphyllum are similar to those of $A$. monophyllum, but it differs in its two leaves, dark red veins in parts of the labellum and length of petioles, the pseudostem and the apex of the anther crest.

Traditional utilization. Even though this species has only recently been discovered, its fresh young leaves are eaten as a vegetable in Northeastern Thai cuisine. 
Amomum chayanianum (Yupparach) Skornick. \& Hlavatá Synonym: Elettariopsis chayaniana Yupparach Vernacular names. Wan Kambang (Chantaburi province). Distribution. It is found in Khao Sapan Hin Range of Amphore Klung, Chantaburi province, Thailand (Figure 1).

Ecology. It grows under the shade of dried evergreen forest at the altitude of 140-500 $\mathrm{m}$ asl.

Note. It closely related to a group of $A$. elan, $A$. slahmong, and A. trilobum based on a clustered-head inflorescence, while others species in Thailand are with an elongated shape. Unique bilobed anther-crest (linear with a bilobed apex) and fruits (ovate with seven longitudinal ridges) are dominant characteristics of $A$. chayaniana. Moreover, the distinctive smell and aroma in leaves of this species differ from other species in this genus. Leaves of $A$. elan give a geranium sweet smell, while A. slahmong yields a distinctive "stinging bug" odor. However, $A$. trilobrum releases weakly smell. Therefore, $A$. chayaniana gives a distinctive smell different from those three species.

Traditional utilization. The local villagers in Chantaburi province, Thailand used this species as a medicinal plant and eaten young leaves as a fresh vegetable.

\section{Amomum curtisii (Baker) Skornick. \& Hlavatá}

Synonym: Elettariopsis curtisii Baker, Cyphostigma curtisii (Baker) K. Schum., and C. serpentinum (Baker) K. Schum.

Vernacular names. Wan (Nakhon Si Thammarat, Phattalung province).

Distribution. It is discovered in Peninsular Thailand: Nakhon Si Thammarat (Khao Luang), Phattalung provinces and Peninsular Malaysia (Figure 1).

Ecology. It grows under the shade of evergreen forest at an altitude of about $1,000 \mathrm{~m}$ asl.

Traditional utilization. The local villagers in Nakhon Si Thammarat, Phattalung provinces, Thailand used this species as medicinal plant and eaten as a fresh vegetable.

\section{Amomum elan (C.K.Lim) Skornick. \& Hlavatá}

Synonym: Elettariopsis elan Lim

Vernacular names. Pud (Southern Thailand).

Distribution. It is reported in Peninsular Thailand: Yala (Hala Forest) and Peninsular Malaysia (Figure 1).

Ecology. It grows under the shade of evergreen forest at an altitude of about $300 \mathrm{~m}$ asl.

Traditional utilization. The local villagers in the southern part of Thailand used this species as a medicinal plant and eaten young leaves as a fresh vegetable.

\section{Amomum exertum (Scort.) Skornick.\&Hlavatá}

Synonym: Elettariopsis exserta Baker

Vernacular names. Pud (Southern Thailand).

Distribution. It is found in Peninsular Thailand: Yala (Phu Khao Thong, Bala Forest) and Peninsular Malaysia (Figure 1).

Ecology. It grows under the shade of evergreen forest at an altitude of about $300 \mathrm{~m}$ asl.

Note. The plant is often two or three leaves, and may form pseudostems, and is usually not as tall in disturbed forests where the juveniles are re-emerging, thus similar in size to A. curtisii. Apart from the dull finish, the leaves are strongly plicate, whereas they are smooth and not prominently veins in $A$. curtisii; both are coriaceous. In keeping with the scale of a plant, the inflorescence is often longly "exserted" out of leaf litter; the flowers are quite similar to others in the genus.

Traditional utilization. The local villagers in the southern part of Thailand recognized for uses this species as a medicinal plant and eaten young leaves as a fresh vegetable.

\section{Amomum monophyllum Gagnep.}

Synonym: Elettariopsis monophylla (Gagnep.) Loes.

Vernacular names. Pud Bai Diew.

Distribution. It is distributed in North-eastern Thailand: Bueng Kan, Nakhon Phanom and Nong Khai provinces; South China (Yunan and Hainan Provinces); Peninsular Malaysia; Laos (Luang Prabang, Vientiane and Savannakhet Provinces) (Figure 1).

Ecology. This species grows under the shade of mixed deciduous forests to dry evergreen forests, at the altitude of c. $140 \mathrm{~m}$ asl.

Note. Large population of this species was recently discovered in the protected area of the forest in Bueng Kan, Nakhon Phanom and Nong Khai provinces of Thailand, only less than $30 \mathrm{~km}$ away from the Mekhong River.

Traditional utilization. The local people in Nakhon Phanom province, the northeastern part of Thailand used this species as a medicinal plant and eaten young leaves as a fresh vegetable.

\section{Amomum slahmong (C.K. Lim) Skornick. \& Hlavatá}

Synonym: Elettariopsis slahmong Lim

Vernacular names. Pud (Southern Thailand).

Distribution. It is distributed in Peninsular Thailand: Yala (Phu Khao Thong, Bala Forest) and Peninsular Malaysia (Figure 1).

Ecology. This species grows under the shade of evergreen forest, at the altitude of c. $600 \mathrm{~m}$ asl.

Note. The epithet recognizes the Teminar name (meaning smelly leaves).

Traditional utilization. The local people in the southern part of Thailand used this species as a medicinal plant and eaten young leaves as a fresh vegetable.

\section{Amomum smithiae (Y.K. Kam) Skornick. \& Hlavatá}

Synonym: Elettariopsis smithiae Y.K. Kam

Vernacular names. Pud (Southern Thailand).

Distribution. It is found in Peninsular Thailand: Song Kla (Than Pliu Waterfall), Satun (Thaleban National Park) and Peninsular Malaysia (Figure 1).

Ecology. This species grows under the shade of evergreen forest, at the altitude of c. $700 \mathrm{~m}$ asl.

Note. Named after R.M. Smith of Edinburgh, Scotland, UK.

Traditional utilization. The local people in the southern part of Thailand used this species as medicinal plant and eaten young leaves as a fresh vegetable. 
Amomum trilobum Gagnep.

Synonym: Elettariopsis triloba (Gagnep.) Loes.

Vernacular names. Pud-Noo (Northeastern Thailand).

Distribution. It is found in North-eastern Thailand: Sakon Nakhon (Phu Phan National Park) and Peninsular Malaysia (Figure 1).

Ecology. This species grows under the shade of mixdeciduous to dry evergreen forests, at the altitude of c. 400 $\mathrm{m}$ asl.

Traditional utilization. The villagers in the northeastern part of Thailand have eaten the young rhizome and young fruit of this plant as fresh vegetable.

Amomum wandokthong (Picheans. \& Yupparach) Skornick. \& Hlavatá

Synonym: Elettariopsis wandokthong Picheans. \& Yupparach

Vernacular names. Wan Dok Thong or Wan Maha Saneh.

Distribution. This species is widely cultivated in Thailand.

Ecology. This species grows under the shade of dry deciduous forest, at the altitude of 62-240 $\mathrm{m}$ asl.

Note. Named after Thai local name.

Traditional utilization. It is ritual plant. This species is believed to process a magical power, and therefore, it is used as a good-luck charm. The Thai names imply magical seductive power. The plants are grown in pots, and put in front of shops believing that they will help to attract customers, especially when the plant is in bloom (usually as early as January to early May). The rhizomes of this species are also used as one of the ingredients for making "magical herbal charming oil" or "magical charming lip balm", believing that after applying it to one's body (oil) or lips (lip balm), it will help to attract the targeted opposite sex, particularly women. Moreover, this species is used for ornamental plants.

Members of the genus Amomum previously Elettariopsis from Thailand can be divided into two groups, i.e. the group with a clustered-head inflorescence, and the group with an elongated shape which corresponds to Picheansoonthon and Yupparach (2007), Saensouk and Saensouk (2014), and Saensouk et al. (2016). This species, together with $A$. elan, A. slahmong, and A. trilobum belongs to the first group. Among these 3 species, A. wandokthong is morphologically closest to A. trilobum, particularly the anther crest. The connective appendages of both species are similar in the presence of the small (c. $1 \mathrm{~mm}$ long) toothlike lobes at the base on each side. This result found ten species of the genus Amomum former Elettariopsis in Thailand which differs from previously reported by Picheansoonthon and Yupparach (2007) and Saensouk et al. (2016). The traditional uses are found to be local food (including ingredients), medicinal, ornamentals and rituals which consistent with the report of Saensouk et al. (2016). Amomum curtisii, A. monophyllum, A. trilobum and A. wandokthong were reported as rare plants followed Picheansoonthon and Yupparach (2007) and Saensouk et al. (2016). Moreover, most species of this study are distributed in the southern part of Thailand except $A$. wandokthong is wildly cultivated in all parts of Thailand which correspond to Picheansoonthon and Yupparach (2007), Saensouk and Saensouk (2014).

\section{Cytological study of four species in genus Amomum former Elettariopsis from Thailand}

The somatic chromosome numbers, karyotype formula, and chromosome structures with satellite positions from four species of genus Amomum from Thailand, namely Amomum curtisii, A. monophyllum, A. trilobum, and A. wandokthong obtained in this current study are presented in Table 2, Figures 2-3.

\section{Amomum curtisii.}

The number of somatic chromosomes of A. curtisii was found to be $2 n=48$ (Figure 2.A). The shortest chromosome length was $0.55 \pm 0.01 \mu \mathrm{m}$, the longest chromosome length was $2.44 \pm 0.11 \mu \mathrm{m}$ and the total chromosome length of the individual chromosomes ranged between $1.99 \pm 0.03$ to $4.47 \pm 0.24 \mu \mathrm{m}$. According to the centromeric index (CI), chromosome ranged from 0.53 to 0.74 , and the relative lengths (RL\%) ranged from 2.70 to 6.09 . The karyological information of $A$. curtisii has 16 metacentric pairs, four submetacentric pairs, and four subtelocentric pairs of chromosomes and the karyotype formula was determined to be $32 \mathrm{~m}+8 \mathrm{sm}+8 \mathrm{st}$, which was observed as asymmetrical karyotypes (Table 3, Figure 3.A). The results correspond with the gametic number $(n=24)$, which is reported for Elettariopsis by Beltran and Kam (1984). Moreover, Chen and Huang (1996) concluded that the basic number of Elettariopsis was $x=12$. The karyotype of this species was studied for the first time.

\section{Amomum monophyllum}

The number of somatic chromosomes of $A$. monophyllum was found to be $2 n=48$ (Figure 2.B). The shortest chromosome length was $0.50 \pm 0.05 \mu \mathrm{m}$, the longest chromosome length was $2.49 \pm 0.14 \mu \mathrm{m}$ and the total chromosome length of the individual chromosomes ranged between $1.33 \pm 0.08$ to $3.73 \pm 0.23 \mu \mathrm{m}$. According to the centromeric index $(\mathrm{CI})$, chromosomes ranged from 0.50 to 0.77 , and the relative lengths (RL\%) ranged from 2.17 to 6.09 . The karyological information of $A$. monophyllum has 13 metacentric pairs, six submetacentric pairs, and five subtelocentric pairs of chromosomes and the karyotype formula was determined to be $26 \mathrm{~m}+12 \mathrm{sm}+$ 10st, which was observed as asymmetrical karyotypes (Table 4, Figure 3.B). This is the first report of the karyotype for this species.

\section{Amomum trilobum}

The number of somatic chromosomes for A. trilobum was $2 n=48$ (Figure 2.C). The shortest chromosome length was $1.32 \pm 0.07 \mu \mathrm{m}$, the longest chromosome length was $5.80 \pm 0.17 \mu \mathrm{m}$ and the total chromosome length of the individual chromosomes ranged between $3.78 \pm 0.10$ to $8.30 \pm 0.27 \mu \mathrm{m}$. According to the centromeric index (CI), chromosomes ranged from 0.50 to 0.74 , and the relative lengths (RL\%) ranged from 3.15 to 6.91 . The karyological information of A. trilobum has nine metacentric pairs, 12 submetacentric pairs, and three subtelocentric pairs of chromosomes and the karyotype formula was determined to be $18 \mathrm{~m}+24 \mathrm{sm}+6 \mathrm{st}$, which was observed as asymmetrical karyotypes (Table 5, Figure 3.C). The results 
correspond with the gametic number $(n=24)$, which was reported for Elettariopsis (Beltran and Kam 1984), and this chromosome number agrees with a previous count by Eksomtramage et al. (2001) who reported $2 n=48$.
Moreover, Chen and Huang (1996) concluded that the basic number of Elettariopsis was $\mathrm{x}=12$. The karyotype of this species was studied for the first time.
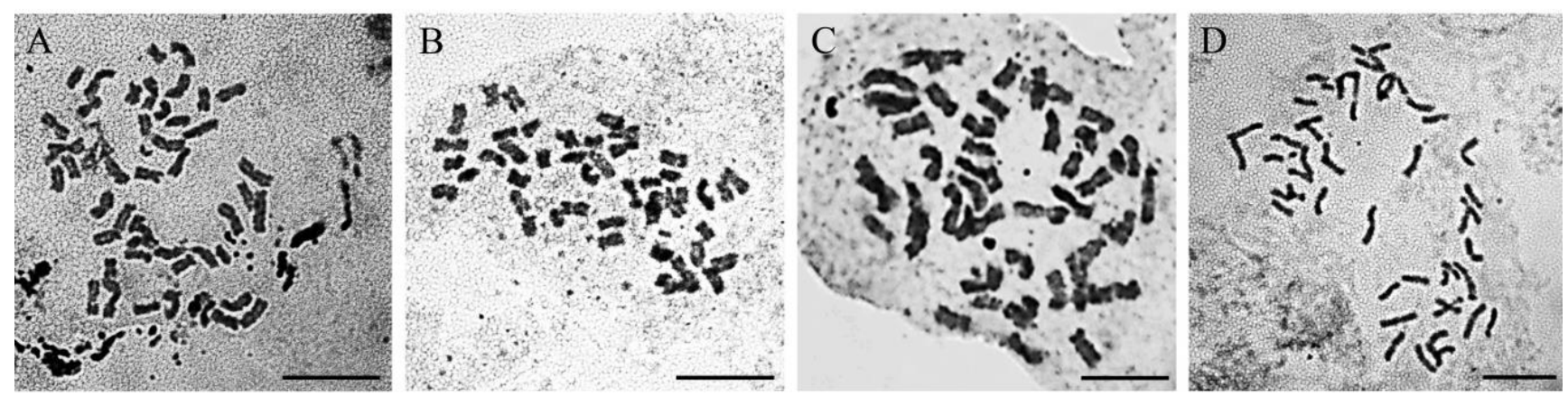

Figure 2. Microphotographs of somatic metaphase plate. A. Amomum curtisii, (B. A. monophyllum, (C. A. trilobum, and (D. A. wandokthong. Scale bars $=10 \mu \mathrm{m}$.

A

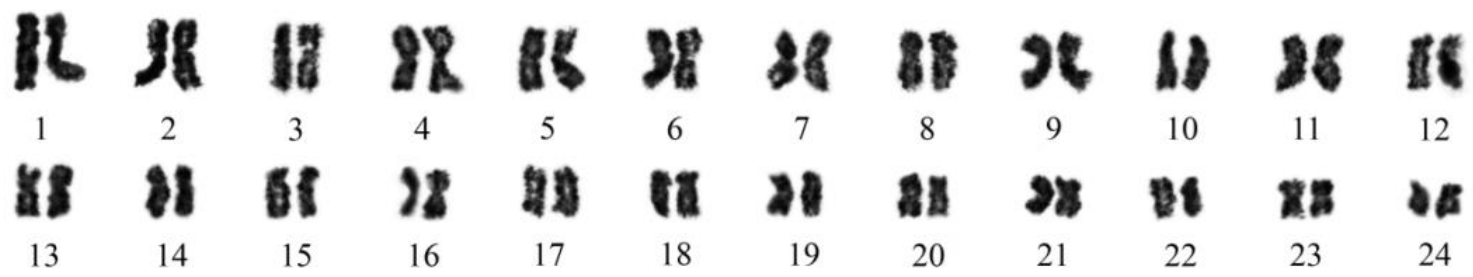

$\mathbf{B}$

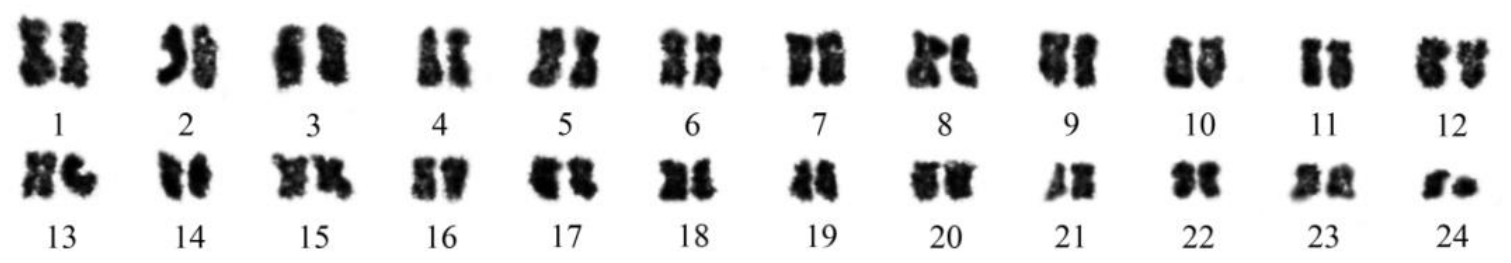

C
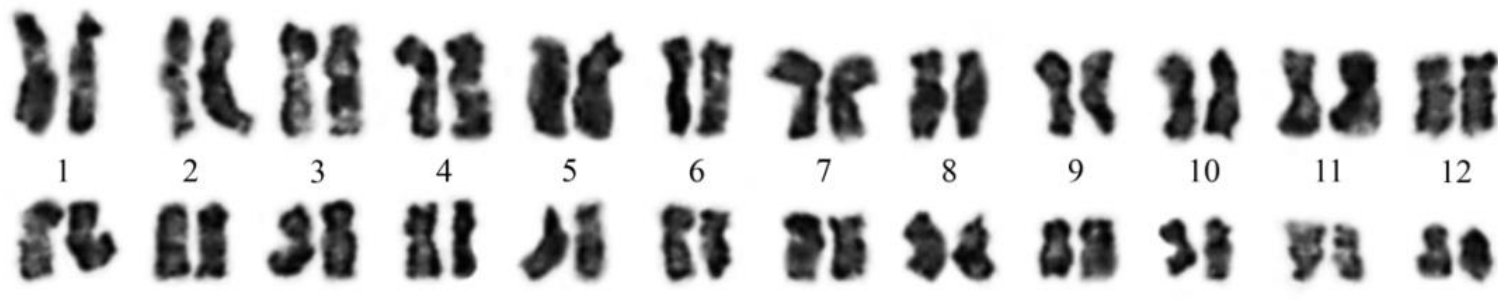

13

16

$17 \quad 18$

$19 \quad 20$

21

22

23
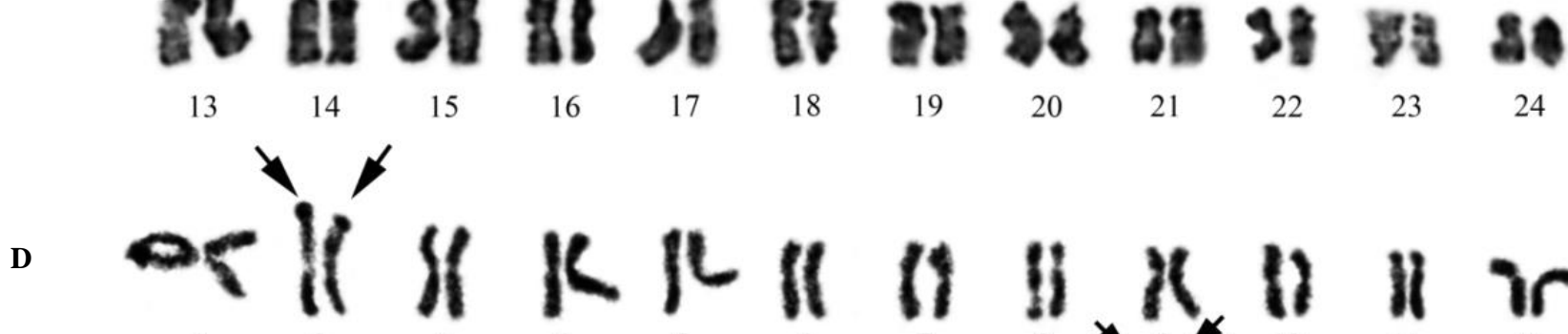

18

23
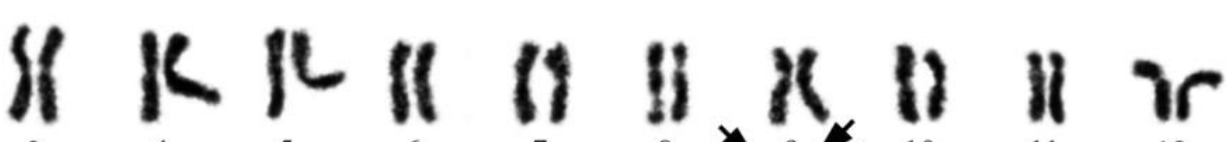

13
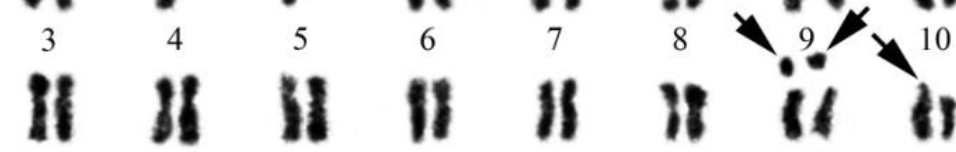

11

12

II it il is

28 )

$13 \quad 14$

15

16

17

18

19

20

21

22

23

24

Figure 3. Karyotypes by conventional staining. A. Amomum curtisii, B. A. monophyllum, C. A. trilobum, and D. A. wandokthong. Arrows in B and E indicate satellites. Scale bar $=10 \mu \mathrm{m}$ 
Amomum wandokthong

The number of somatic chromosomes of $A$. wandokthong was $2 n=48$ (Figure 2.D). The shortest chromosome length was $1.28 \pm 0.05 \mu \mathrm{m}$, the longest chromosome length was $4.25 \pm 0.09 \mu \mathrm{m}$ and the total chromosome length of the individual chromosomes ranged between $2.80 \pm 0.10$ to $8.01 \pm 0.28 \mu \mathrm{m}$. According to the centromeric index $(\mathrm{CI})$, chromosomes ranged from 0.50 to 0.76 , and the relative lengths (RL\%) ranged from 2.15 to
6.14. The karyological information of A. wandokthong has 14 metacentric pairs, eight submetacentric pairs, two subtelocentric pairs, and five visible satellite chromosomes. The environmental factors are affected to be satellite chromosomes of this plant. The karyotype formula was determined as $28 \mathrm{~m}+16 \mathrm{sm}+4 \mathrm{st}$, which was observed as asymmetrical karyotypes (Table 6, Figure 3.D). This is the first report of the chromosome number and karyotype for this species.

Table 2. Summary of previous reports of somatic chromosome numbers studied in former genus Elettariopsis

\begin{tabular}{|c|c|c|c|c|c|}
\hline Species & $2 n$ & $\mathbf{n}$ & Karyotype formula & Location & References \\
\hline $\begin{array}{l}\text { E. biphylla } \\
\text { (Synonym of A. biphyllum) }\end{array}$ & 48 & - & $18 \mathrm{~m}+26 \mathrm{sm}+4 \mathrm{st}$ & Thailand & Saenprom et al. (2018) \\
\hline $\begin{array}{l}\text { E. burtiana } \\
\text { (Synonym of } A . \text { billburttii) }\end{array}$ & - & 24 & - & Malaysia & Kam (1982) \\
\hline E. curtisii & - & 24 & - & Malaysia & Kam (1982) \\
\hline \multirow[t]{2}{*}{ (Synonym of A. curtisii) } & - & 24 & - & Malaysia & Beltran and Kam (1984) \\
\hline & 48 & - & $32 \mathrm{~m}+8 \mathrm{sm}+8 \mathrm{st}$ & Thailand & Present study* \\
\hline $\begin{array}{l}\text { E. monophylla } \\
\text { (Synonym of A. monophyllum) }\end{array}$ & 48 & - & $26 m+12 s m+10 s t$ & Thailand & Present study* \\
\hline E. smithiae & - & 24 & - & Malaysia & $\operatorname{Kam}(1982)$ \\
\hline (Synonym of A. smithiae) & - & 24 & - & Malaysia & Beltran and Kam (1984) \\
\hline E. triloba & - & 24 & - & Malaysia & Beltran and Kam (1984) \\
\hline \multirow[t]{2}{*}{ (Synonym of A. trilobum) } & 48 & - & - & Thailand & Eksomtramage et al. (2001) \\
\hline & 48 & - & $18 m+24 s m+6 s t$ & Thailand & Present study* \\
\hline E. trilobum & - & 24 & - & Malaysia & $\operatorname{Kam}(1982)$ \\
\hline (Synonym of A. trilobum) & - & 24 & - & Malaysia & Beltran and Kam (1984) \\
\hline $\begin{array}{l}\text { E. wandokthong } \\
\text { (Synonym of A. wandokthong) }\end{array}$ & 48 & - & $\begin{array}{l}28 \mathrm{~m}+16 \mathrm{sm}+4 \mathrm{st} \\
\text { (five visible satellites) }\end{array}$ & Thailand & Present study*,** \\
\hline
\end{tabular}

Note: *: First report, **: Shows satellites

Table 3.Chromosome characters of Amomum curtisii

\begin{tabular}{|c|c|c|c|c|c|c|}
\hline $\begin{array}{l}\text { Chromosome } \\
\text { pair }\end{array}$ & $\mathbf{L s} \pm \mathbf{S D}(\boldsymbol{\mu m})$ & $\mathrm{Ll} \pm \mathrm{SD}(\boldsymbol{\mu m})$ & $\mathbf{L T} \pm \mathbf{S D}(\boldsymbol{\mu m})$ & $\mathbf{R L}(\%)$ & CI & Chromosome Shape \\
\hline 1 & $2.11 \pm 0.08$ & $2.36 \pm 0.16$ & $4.47 \pm 0.24$ & 6.09 & 0.53 & Metacentric \\
\hline 2 & $1.75 \pm 0.08$ & $2.38 \pm 0.02$ & $4.13 \pm 0.20$ & 5.63 & 0.58 & Metacentric \\
\hline 3 & $1.32 \pm 0.06$ & $2.44 \pm 0.11$ & $3.75 \pm 0.17$ & 5.11 & 0.65 & Submetacentric \\
\hline 4 & $1.66 \pm 0.06$ & $2.18 \pm 0.11$ & $3.84 \pm 0.16$ & 5.23 & 0.57 & Metacentric \\
\hline 5 & $1.49 \pm 0.04$ & $2.13 \pm 0.10$ & $3.62 \pm 0.13$ & 4.93 & 0.59 & Metacentric \\
\hline 6 & $1.45 \pm 0.04$ & $1.97 \pm 0.08$ & $3.42 \pm 0.11$ & 4.66 & 0.58 & Metacentric \\
\hline 8 & $1.40 \pm 0.00$ & $1.95 \pm 0.08$ & $3.35 \pm 0.07$ & 4.56 & 0.58 & Metacentric \\
\hline 9 & $1.41 \pm 0.00$ & $1.87 \pm 0.07$ & $3.28 \pm 0.07$ & 4.47 & 0.57 & Metacentric \\
\hline 10 & $0.85 \pm 0.02$ & $2.42 \pm 0.05$ & $3.27 \pm 0.06$ & 4.45 & 0.74 & Subtelocentric \\
\hline 11 & $1.32 \pm 0.02$ & $1.88 \pm 0.05$ & $3.20 \pm 0.06$ & 4.36 & 0.59 & Metacentric \\
\hline 12 & $1.15 \pm 0.00$ & $1.99 \pm 0.09$ & $3.13 \pm 0.09$ & 4.27 & 0.63 & Submetacentric \\
\hline 13 & $1.32 \pm 0.00$ & $1.80 \pm 0.09$ & $3.13 \pm 0.09$ & 4.26 & 0.58 & Metacentric \\
\hline 14 & $1.10 \pm 0.00$ & $1.96 \pm 0.03$ & $3.07 \pm 0.03$ & 4.18 & 0.64 & Submetacentric \\
\hline 16 & $1.15 \pm 0.06$ & $1.55 \pm 0.05$ & $2.70 \pm 0.11$ & 3.68 & 0.57 & Metacentric \\
\hline 17 & $0.88 \pm 0.00$ & $1.77 \pm 0.01$ & $2.65 \pm 0.01$ & 3.61 & 0.67 & Submetacentric \\
\hline 18 & $0.66 \pm 0.00$ & $1.98 \pm 0.02$ & $2.64 \pm 0.02$ & 3.60 & 0.75 & Subtelocentric \\
\hline 19 & $1.02 \pm 0.04$ & $1.35 \pm 0.06$ & $2.37 \pm 0.09$ & 3.23 & 0.57 & Metacentric \\
\hline 20 & $0.98 \pm 0.00$ & $1.32 \pm 0.00$ & $2.30 \pm 0.00$ & 3.13 & 0.57 & Metacentric \\
\hline 21 & $0.99 \pm 0.02$ & $1.28 \pm 0.03$ & $2.27 \pm 0.05$ & 3.10 & 0.56 & Metacentric \\
\hline 22 & $0.98 \pm 0.01$ & $1.25 \pm 0.02$ & $2.24 \pm 0.03$ & 3.05 & 0.56 & Metacentric \\
\hline 23 & $0.90 \pm 0.01$ & $1.32 \pm 0.03$ & $2.22 \pm 0.04$ & 3.02 & 0.59 & Metacentric \\
\hline 24 & $0.55 \pm 0.01$ & $1.44 \pm 0.02$ & $1.99 \pm 0.03$ & 2.70 & 0.72 & Subtelocentric \\
\hline
\end{tabular}

Note: Ls: mean length of short arm chromosome, L1: long arm chromosome, LT: total arm chromosome, RL: relative length, CI: centromeric index, and SD: standard deviation (SD) 
Table 4. Chromosome characters of Amomum monophyllum

\begin{tabular}{|c|c|c|c|c|c|c|}
\hline $\begin{array}{l}\text { Chromosome } \\
\text { pair }\end{array}$ & $\mathbf{L s} \pm \mathbf{S D}(\mu \mathrm{m})$ & $\mathrm{Ll} \pm \mathrm{SD}(\mu \mathrm{m})$ & $\mathbf{L T} \pm \mathbf{S D}(\boldsymbol{\mu m})$ & RL (\%) & CI & Chromosome shape \\
\hline 1 & $1.54 \pm 0.09$ & $2.20 \pm 0.13$ & $3.73 \pm 0.23$ & 6.09 & 0.59 & Metacentric \\
\hline 2 & $1.01 \pm 0.07$ & $2.49 \pm 0.14$ & $3.50 \pm 0.22$ & 5.70 & 0.71 & Subtelocentric \\
\hline 3 & $1.00 \pm 0.08$ & $2.49 \pm 0.11$ & $3.49 \pm 0.20$ & 5.69 & 0.71 & Subtelocentric \\
\hline 4 & $1.29 \pm 0.08$ & $2.20 \pm 0.13$ & $3.49 \pm 0.22$ & 5.69 & 0.63 & Submetacentric \\
\hline 5 & $1.74 \pm 0.10$ & $1.74 \pm 0.11$ & $3.47 \pm 0.22$ & 5.66 & 0.50 & Metacentric \\
\hline 6 & $1.59 \pm 0.09$ & $1.76 \pm 0.11$ & $3.35 \pm 0.21$ & 5.46 & 0.52 & Metacentric \\
\hline 7 & $1.29 \pm 0.09$ & $2.00 \pm 0.09$ & $3.29 \pm 0.19$ & 5.36 & 0.61 & Submetacentric \\
\hline 8 & $1.32 \pm 0.08$ & $1.87 \pm 0.12$ & $3.18 \pm 0.21$ & 5.19 & 0.59 & Metacentric \\
\hline 9 & $1.32 \pm 0.08$ & $1.76 \pm 0.11$ & $3.08 \pm 0.19$ & 5.01 & 0.57 & Metacentric \\
\hline 10 & $0.65 \pm 0.04$ & $2.20 \pm 0.13$ & $2.85 \pm 0.18$ & 4.65 & 0.77 & Subtelocentric \\
\hline 11 & $1.09 \pm 0.06$ & $1.76 \pm 0.11$ & $2.85 \pm 0.18$ & 4.65 & 0.62 & Submetacentric \\
\hline 12 & $1.11 \pm .060$ & $1.52 \pm 0.09$ & $2.64 \pm 0.17$ & 4.30 & 0.58 & Metacentric \\
\hline 13 & $1.00 \pm 0.06$ & $1.59 \pm 0.11$ & $2.59 \pm 0.19$ & 4.22 & 0.61 & Submetacentric \\
\hline 14 & $0.71 \pm 0.05$ & $1.69 \pm 0.11$ & $2.40 \pm 0.17$ & 3.91 & 0.71 & Subtelocentric \\
\hline 15 & $0.98 \pm 0.06$ & $1.00 \pm 0.06$ & $1.98 \pm 0.13$ & 3.23 & 0.50 & Metacentric \\
\hline 16 & $0.87 \pm 0.05$ & $1.11 \pm 0.08$ & $1.98 \pm 0.14$ & 3.22 & 0.56 & Metacentric \\
\hline 17 & $0.78 \pm 0.06$ & $1.06 \pm 0.09$ & $1.84 \pm 0.16$ & 3.00 & 0.58 & Metacentric \\
\hline 18 & $0.78 \pm 0.06$ & $1.02 \pm 0.08$ & $1.80 \pm 0.15$ & 2.94 & 0.57 & Metacentric \\
\hline 19 & $0.50 \pm 0.05$ & $1.30 \pm 0.09$ & $1.80 \pm 0.15$ & 2.94 & 0.72 & Subtelocentric \\
\hline 20 & $0.58 \pm 0.05$ & $1.12 \pm 0.08$ & $1.70 \pm 0.14$ & 2.77 & 0.66 & Submetacentric \\
\hline 21 & $0.56 \pm 0.04$ & $1.12 \pm 0.08$ & $1.68 \pm 0.13$ & 2.74 & 0.67 & Submetacentric \\
\hline 22 & $0.70 \pm 0.05$ & $0.96 \pm 0.07$ & $1.66 \pm 0.13$ & 2.71 & 0.58 & Metacentric \\
\hline 23 & $0.69 \pm 0.04$ & $0.97 \pm 0.07$ & $1.66 \pm 0.12$ & 2.70 & 0.59 & Metacentric \\
\hline 24 & $0.54 \pm 0.03$ & $0.79 \pm 0.05$ & $1.33 \pm 0.08$ & 2.17 & 0.59 & Metacentric \\
\hline
\end{tabular}

Note: Ls: mean length of short arm chromosome, L1: long arm chromosome, LT: total arm chromosome, RL: relative length, CI: centromeric index, and SD: standard deviation (SD)

Table 5. Chromosome characters of Amomum trilobum

\begin{tabular}{|c|c|c|c|c|c|c|}
\hline $\begin{array}{l}\text { Chromosome } \\
\text { pair }\end{array}$ & $\mathbf{L s} \pm \mathrm{SD}(\mu \mathrm{m})$ & $\mathrm{Ll} \pm \mathrm{SD}(\mu \mathrm{m})$ & $\mathbf{L T} \pm \mathrm{SD}(\mu \mathrm{m})$ & RL (\%) & CI & Chromosome shape \\
\hline 1 & $2.50 \pm 0.09$ & $5.80 \pm 0.17$ & $8.30 \pm 0.27$ & 6.91 & 0.70 & Subtelocentric \\
\hline 2 & $2.70 \pm 0.08$ & $4.86 \pm 0.17$ & $7.56 \pm 0.26$ & 6.29 & 0.64 & Submetacentric \\
\hline 3 & $2.85 \pm 0.09$ & $4.52 \pm 0.13$ & $7.38 \pm 0.23$ & 5.48 & 0.61 & Submetacentric \\
\hline 4 & $2.88 \pm 0.09$ & $4.48 \pm 0.14$ & $7.36 \pm 0.25$ & 5.27 & 0.61 & Submetacentric \\
\hline 5 & $1.78 \pm 0.10$ & $4.01 \pm 0.14$ & $5.79 \pm 0.25$ & 4.82 & 0.69 & Submetacentric \\
\hline 6 & $1.81 \pm 0.09$ & $3.62 \pm 0.13$ & $5.43 \pm 0.23$ & 4.52 & 0.67 & Submetacentric \\
\hline 7 & $2.20 \pm 0.10$ & $3.20 \pm 0.11$ & $5.40 \pm 0.22$ & 4.49 & 0.59 & Metacentric \\
\hline 8 & $1.35 \pm 0.08$ & $3.83 \pm 0.14$ & $5.18 \pm 0.22$ & 4.31 & 0.74 & Subtelocentric \\
\hline 9 & $2.27 \pm 0.09$ & $2.81 \pm 0.12$ & $5.07 \pm 0.22$ & 4.22 & 0.55 & Metacentric \\
\hline 10 & $2.19 \pm 0.05$ & $2.80 \pm 0.14$ & $4.99 \pm 0.20$ & 4.16 & 0.56 & Metacentric \\
\hline 11 & $2.22 \pm 0.08$ & $2.71 \pm 0.12$ & $4.93 \pm 0.21$ & 4.10 & 0.55 & Metacentric \\
\hline 12 & $1.32 \pm 0.07$ & $3.48 \pm 0.11$ & $4.79 \pm 0.19$ & 3.99 & 0.73 & Subtelocentric \\
\hline 13 & $1.79 \pm 0.07$ & $2.99 \pm 0.12$ & $4.78 \pm 0.21$ & 3.98 & 0.63 & Submetacentric \\
\hline 14 & $1.74 \pm 0.06$ & $2.84 \pm 0.12$ & $4.57 \pm 0.19$ & 3.81 & 0.62 & Submetacentric \\
\hline 15 & $1.49 \pm 0.07$ & $2.90 \pm 0.08$ & $4.39 \pm 0.16$ & 3.65 & 0.66 & Submetacentric \\
\hline 16 & $1.96 \pm 0.06$ & $2.20 \pm 0.09$ & $4.15 \pm 0.16$ & 3.46 & 0.53 & Metacentric \\
\hline 17 & $1.32 \pm 0.07$ & $2.79 \pm 0.11$ & $4.11 \pm 0.18$ & 3.42 & 0.68 & Submetacentric \\
\hline 18 & $1.57 \pm 0.06$ & $2.53 \pm 0.09$ & $4.11 \pm 0.17$ & 3.42 & 0.62 & Submetacentric \\
\hline 19 & $1.45 \pm 0.06$ & $2.60 \pm 0.09$ & $4.05 \pm 0.16$ & 3.37 & 0.64 & Submetacentric \\
\hline 20 & $1.82 \pm 0.06$ & $2.20 \pm 0.09$ & $4.03 \pm 0.16$ & 3.35 & 0.55 & Metacentric \\
\hline 21 & $1.50 \pm 0.04$ & $2.50 \pm 0.09$ & $4.00 \pm 0.14$ & 3.33 & 0.63 & Submetacentric \\
\hline 22 & $1.85 \pm 0.06$ & $2.08 \pm 0.08$ & $3.93 \pm 0.15$ & 3.27 & 0.53 & Metacentric \\
\hline 23 & $1.90 \pm 0.05$ & $2.00 \pm 0.08$ & $3.90 \pm 0.13$ & 3.24 & 0.51 & Metacentric \\
\hline 24 & $1.90 \pm 0.03$ & $1.88 \pm 0.06$ & $3.78 \pm 0.10$ & 3.15 & 0.50 & Metacentric \\
\hline
\end{tabular}

Note: Ls: mean length of short arm chromosome, L1: long arm chromosome, LT: total arm chromosome, RL: relative length, CI: centromeric index, and SD: standard deviation (SD) 
Table 6. Chromosome characters of Amomum wandokthong

\begin{tabular}{|c|c|c|c|c|c|c|}
\hline $\begin{array}{l}\text { Chromosome } \\
\text { pair }\end{array}$ & $\mathbf{L s} \pm \mathrm{SD}(\boldsymbol{\mu m})$ & $\mathrm{Ll} \pm \mathrm{SD}(\mu \mathrm{m})$ & $\mathbf{L T} \pm \mathbf{S D}(\mu \mathrm{m})$ & RL (\%) & CI & Chromosome Shape \\
\hline 1 & $4.00 \pm 0.12$ & $4.01 \pm 0.15$ & $8.01 \pm 0.28$ & 6.14 & 0.50 & Metacentric \\
\hline $2^{*}$ & $3.82 \pm 0.10$ & $4.04 \pm 0.16$ & $7.86 \pm 0.27$ & 6.02 & 0.51 & Metacentric \\
\hline 3 & $3.50 \pm 0.10$ & $3.87 \pm 0.13$ & $7.37 \pm 0.25$ & 5.65 & 0.53 & Metacentric \\
\hline 4 & $3.18 \pm 0.10$ & $3.72 \pm 0.15$ & $6.90 \pm 0.26$ & 5.29 & 0.54 & Metacentric \\
\hline 5 & $2.98 \pm 0.12$ & $3.87 \pm 0.13$ & $6.85 \pm 0.26$ & 5.25 & 0.57 & Metacentric \\
\hline 6 & $2.81 \pm 0.10$ & $3.00 \pm 0.12$ & $5.81 \pm 0.23$ & 4.45 & 0.52 & Metacentric \\
\hline 7 & $2.90 \pm 0.10$ & $2.91 \pm 0.11$ & $5.81 \pm 0.23$ & 4.45 & 0.50 & Metacentric \\
\hline 8 & $2.20 \pm 0.09$ & $3.53 \pm 0.14$ & $5.73 \pm 0.23$ & 4.38 & 0.62 & Submetacentric \\
\hline 9 & $2.28 \pm 0.09$ & $3.42 \pm 0.13$ & $5.70 \pm 0.22$ & 4.36 & 0.60 & Submetacentric \\
\hline 10 & $2.72 \pm 0.06$ & $2.96 \pm 0.14$ & $5.68 \pm 0.21$ & 4.35 & 0.52 & Metacentric \\
\hline 11 & $1.48 \pm 0.07$ & $4.14 \pm 0.13$ & $5.62 \pm 0.21$ & 4.30 & 0.76 & Subtelocentric \\
\hline 12 & $2.52 \pm 0.08$ & $2.99 \pm 0.11$ & $5.51 \pm 0.20$ & 4.22 & 0.54 & Metacentric \\
\hline 13 & $2.10 \pm 0.08$ & $3.40 \pm 0.13$ & $5.50 \pm 0.22$ & 4.21 & 0.62 & Submetacentric \\
\hline 14 & $2.06 \pm 0.07$ & $3.40 \pm 0.13$ & $5.45 \pm 0.20$ & 4.18 & 0.62 & Submetacentric \\
\hline 15 & $1.20 \pm 0.07$ & $4.25 \pm 0.09$ & $5.45 \pm 0.17$ & 4.18 & 0.73 & Subtelocentric \\
\hline 16 & $2.44 \pm 0.07$ & $3.00 \pm 0.10$ & $5.44 \pm 0.18$ & 4.16 & 0.55 & Metacentric \\
\hline 17 & $1.94 \pm 0.07$ & $3.37 \pm 0.11$ & $5.31 \pm 0.20$ & 4.06 & 0.63 & Submetacentric \\
\hline 18 & $1.98 \pm 0.07$ & $3.20 \pm 0.10$ & $5.18 \pm 0.18$ & 3.96 & 0.62 & Submetacentric \\
\hline 19 & $1.68 \pm 0.06$ & $3.16 \pm 0.11$ & $4.84 \pm 0.18$ & 3.70 & 0.65 & Submetacentric \\
\hline 20 & $1.91 \pm 0.06$ & $1.99 \pm 0.09$ & $3.90 \pm 0.16$ & 2.99 & 0.51 & Metacentric \\
\hline $21 *$ & $1.37 \pm 0.05$ & $2.42 \pm 0.09$ & $3.79 \pm 0.15$ & 2.90 & 0.64 & Submetacentric \\
\hline 22 & $1.35 \pm 0.06$ & $1.75 \pm 0.08$ & $3.11 \pm 0.15$ & 2.38 & 0.56 & Metacentric \\
\hline 23 & $1.28 \pm 0.05$ & $1.70 \pm 0.07$ & $2.98 \pm 0.13$ & 2.28 & 0.57 & Metacentric \\
\hline 24 & $1.39 \pm 0.04$ & $1.41 \pm 0.05$ & $2.80 \pm 0.10$ & 2.15 & 0.50 & Metacentric \\
\hline
\end{tabular}

Note: *: satellite chromosome, Ls: mean length of short arm chromosome, L1: long arm chromosome, LT: total arm chromosome, RL: relative length, $\mathrm{CI}$ : centromeric index, and $\mathrm{SD}$ : standard deviation (SD)

In conclusion, ten species of Amomum former Elettariopsis were recognized in Thailand, namely $A$. biphyllum, A. curtisii, A. chayaniana, A. elan, A. exserta, A. monophyllum, A. slahmong, A. smithiae, A. trilobum, and A. wandokthong. The chromosome number of four species in the Amomum from Thailand is $2 \mathrm{n}=48$. The karyotypes of $A$. curtisii is $32 \mathrm{~m}+8 \mathrm{sm}+8 \mathrm{st}$, A. monophylla is $26 \mathrm{~m}+$ $12 \mathrm{sm}+10 \mathrm{st}$, A. triloba is $18 \mathrm{~m}+24 \mathrm{sm}+6 \mathrm{st}$, and $A$. wandokthong is $28 \mathrm{~m}+16 \mathrm{sm}+4 \mathrm{st}$ with five visible satellite chromosomes. The chromosome structures of all species were found to be asymmetrical.

\section{ACKNOWLEDGEMENTS}

We are deeply indebted to the National Science and Technology Development Agency (FDA-CO-2563-11240$\mathrm{TH})$ for financial support. We are grateful to the Walai Rukhavej Botanical Research Institute and Laboratory Equipment Center, the Center of Excellence for Silk Innovation, Division of Research Facilitation and Dissemination, Mahasakham University, Thailand for their facilities during this study. We thank also the Curators and staff of the herbaria visited in other countries, Dr. Rattanavalee Senavongse for her help in laboratory techniques, and Dr. Jolyon Dodgson for language editing and suggestions to improve the manuscript.

\section{REFERENCES}

Baker JG. 1892. Scitamineae. In: Hooker F (eds). Flora of British India. Reeve, Kent, London.

Boer H, Newman M, Poulsen AD, Droop AJ, Fer T, Thu Hiền LT, Hlavat K, Lamxay V, Richardson JE, Steffen K, Leong-Škorničková J. 2018. Convergent morphology in Alpinieae (Zingiberaceae): Recircumscribing Amomum as a monophyletic genus. Taxon 67(1): 636. DOI: $10.12705 / 671.2$

Beltran IC, Kam YK. 1984. Cytotaxonomic studies in the Zingiberaceae. Notes - Roy Bot Gard Edinburgh 41 (3): 541-559.

Chen ZY, Huang XX. 1996. Cytotaxonomy of the tribe Alpineae. In: Wu TL,Wu QG, ChenZY (eds). Proceedings of the 2 nd symposium on the family Zingiberaceae. Zhongshan University Press, Guangzhou.

Eksomtramage L, Sirirugsa P, Sawangchote P, Jornead S, Saknimit T, Leeratiwong C. 2001. Chromosome numbers of some monocot species from Ton-Nga-Chang Wildlife Sanctuary, Southern Thailand. Thai For Bull Bot 29:63-71.

International Plant Names Index (IPNI). 2020. http://www.ipni.org; Accessed 12 April 2020.

KewScience. 2020. World checklist of selected plant families (WCSP). http://apps.kew.org/wcsp/; Accessed 12 April 2020.

Kam YK. 1982. The genus Elettariopsis (Zingiberaceae) in Malaya. Notes Roy Bot Gard Edinburgh 40: 139-152.

KressWJ, Newman MF, Poulsen AD, Specht C.2007. An analysis of generic circumscriptions in tribe Alpinieae (Alpinioideae: Zingiberaceae). Gard Bull Singapore 59: 113-128.

Leong-Škorničková $\mathrm{J}$, Trần HĐ, Nguyễn Quốc Bình, Kristýna Hlavatá, Lưu Hồng Trường, Nguyễ̂n Quốc Đạt, Nguyễn Thành Trung, Newman M.2019. The identity of Amomum trilobum and Amomum unifolium (Zingiberaceae: Alpinioideae), and description of four new related species from Vietnam. Phytotaxa 401(3):149-165. DOI: $10.12705 / 671.2$

Levan A, Fredgra L, Sandberg AA. 1964. Nomenclature for centromeric position on chromosomes. Hereditas 52:201-220. DOI: 10.1111/j.1601-5223.1964.tb01953.x 
Picheansoonthon C, Yupparach P. 2007. Notes on the genus Elettariopsis Baker (Zingiberaceae) in Thailand. J Thai Trad AltMed 5: 267-78.

Roxburgh W. 1820.Plants of the coast of Coromandel, Vol. 3. Bulmer and Co., London. https://doi.org/10.5962/bhl.title.467

Saenprom K, Saensouk S, Saensouk P, Senakun C. 2018. Karyomorphological analysis of four species of Zingiberaceae from Thailand. Nucleus 61: 111-120. DOI: 10.1007/s13237-018-0235-x

Saensouk S, Saensouk P. 2014. Elettariopsisbiphylla, a new species of Zingiberaceae from Thailand. Phytotaxa 159: 23-25. DOI: 0.11646/phytotaxa.159.1.4
Saensouk S, Saensouk P, Pasorn P, Chantaranothai P. 2016. Diversity, Traditional Uses and New Record of Zingiberaceae in Nam Nao National Park, Petchabun Province, Thailand. Agriculture and Natural Resources 50: 445-453. DOI: 0.1016/j.anres.2016.08.002

Ye XE, Leong-Škorničková J,Xia NH. 2021. Taxonomic studies on Amomum (Zingiberaceae) in China III: Amomum fangdingii, a new species from Guangxi. Phytotaxa 490(3): 263-270. DOI: 10.11646/phytotaxa.490.3. 